\title{
Circulating cytokines in patients undergoing normothermic cardiopulmonary bypass
}

To determine the cytokine release during normothermic cardiopulmonary bypass, we have measured plasmatic levels of tumor necrosis factor- $\alpha$ and interleukins- $1 \beta, 6$, and 8 in 10 patients during the first 24 hours after the start of bypass. Arterial blood samples were collected at intervals before, during, and after bypass. Interleukin- $1 \beta$ was not detectable in the plasma, and traces of tumor necrosis factor- $\alpha$ were detected in only three patients at times independent of the cardiopulmonary bypass procedure. Circulating endotoxin remained undetectable. Plasma interleukin- 6 and interleukin-8 rose significantly from 2 until 24 hours after the start of bypass $(p<0.05)$ and peaked respectively at 4 and 2 hours after the beginning of bypass (interleukin-6, $268.1 \pm 131.43 \mathrm{pg} / \mathrm{ml}$; interleukin-8, $370 \pm 420$ $\mathrm{pg} / \mathrm{ml}$; mean peak \pm standard deviation). Peak values of interleukin- 6 and interleukin- 8 were correlated neither with the duration of aortic crossclamping or the bypass procedure nor with the hemodynamic parameters recorded at the same times. This study shows that normothermic cardiopulmonary bypass does not induce systemic release of tumor necrosis factor- $\alpha$ and interleukin- $1 \beta$. A local production of these cytokines cannot be excluded, because interleukin- 6 and interleukin- 8 are produced by stimulated macrophages and monocytes in response to tumor necrosis factor- $\alpha$ and interleukin- $1 \beta$. Our results, at normothermia, show a similar pattern of interleukin-6 and interleukin-8 release when compared with release during hypothermic cardiopulmonary bypass. Interleukin-8, an important chemotactic neutrophil factor, might play a role in reperfusion injuries observed in lungs and heart after cardiopulmonary bypass. (J THORAC CARDIOvaSC SURG 1994;108:636-41)

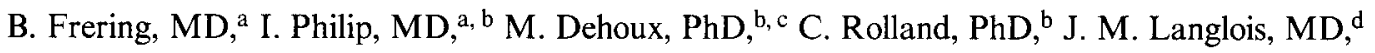
and J. M. Desmonts, $\mathrm{MD}^{\mathrm{a}, \mathrm{b}}$ Paris, France

E during cardiopulmonary bypass (CPB) induces an acute inflammatory response. ${ }^{1}$ After cardiac surgery, this response is a combination of interaction of blood components with artificial surfaces, reperfusion injury, and activation by endotoxin. ${ }^{2,3}$ The inflammatory process might be associated with morbidity caused by organ dysfunction observed after CPB. Different inflammatory

From Département d'Anesthésie et de Réanimation Chirurgicale, ${ }^{a}$ Unité INSERM U408, ${ }^{b}$ Laboratoire de Biochimie A, ${ }^{c}$ and Service de Chirurgie Cardio-vasculaire, ${ }^{d}$ Centre hospitalo-universitaire Bichat, Paris, France.

Received for publication Jan. 11, 1994.

Accepted for publication May 10, 1994.

Address for reprints: I. Philip, MD, Département d'Anesthésie et de Reanimation Chirurgicale, Hopital Bichat, 46 rue Henri-Huchard, 75878 Paris Cedex 18, France.

Copyright ${ }^{(C)} 1994$ by Mosby-Year Book, Inc.

$0022-5223 / 94 \$ 3.00+0 \quad \mathbf{1 2} / \mathbf{1} / \mathbf{5 7 4 3 5}$ pathways are activated after $\mathrm{CPB}$, including the complement system, ${ }^{4,5}$ the contact system, the polymorphonuclear neutrophils, ${ }^{6,7}$ and the mononuclear cells, leading to cytokine release. ${ }^{2,8}$

Indeed, previous studies have reported different patterns of cytokine production after hypothermic CPB. Haeffner-Cavaillon and associates ${ }^{9}$ demonstrated intracellular production of interleukin-1 (IL-1) in monocytes. Interestingly, no circulating IL- $1 \beta$ has been found in the plasma of patients after hypothermic bypass. ${ }^{8,10} \mathrm{Con}-$ flicting data are available for tumor necrosis factor- $\alpha$ (TNF $\alpha$ ), because it remained undetectable in some studies, ${ }^{9-13}$ although others have measured significant plasma values of TNF $\alpha$ after bypass. ${ }^{14,15}$ TNF $\alpha$ and IL-1 $\beta$, when produced in excess, might induce deleterious effects, including endothelial dysfunction with enhanced vascular permeability, decreased systemic vascular resistances, and myocardial depression. ${ }^{16-18}$

High levels of interleukin-6 (IL-6) have been reported after cardiac surgery, $2,8,11,12$ but the clinical relevance 
remains unclear. Neutrophil activation described after CPB might be induced by interleukin-8 (IL-8), known to be a major neutrophil chemotactic factor. ${ }^{19}$ Recent investigations have reported its pathophysiologic role in different clinical situations, particularly in reperfusion injury. ${ }^{20}$ Three studies have found an increase in plasma IL-8 levels after hypothermic CPB. ${ }^{11,21,22}$

Warm heart surgery, with warm blood cardioplegia and normothermic $\mathrm{CPB}$, has been recently introduced. Warm blood cardioplegia seems to be an effective method of myocardial protection. ${ }^{23,24}$ Normothermic CPB shortens $\mathrm{CPB}$ duration and minimizes platelet dysfunction. ${ }^{25}$ Nevertheless, previous studies have reported lower systemic vascular resistance during normothermic $\mathrm{CPB}$ when compared with hypothermic $\mathrm{CPB}{ }^{26,27} \mathrm{~A}$ greater inflammatory response in normothermia, with enhanced complement activation and IL-1 release, has been documented in vitro. ${ }^{9}$ An enhanced cytokine release after normothermic CPB, mainly $\mathrm{TNF} \alpha$ and IL- $1 \beta$, might partly explain hemodynamic differences between warm and cold surgery.

The aim of our prospective work was to measure circulating concentrations of TNF $\alpha$, IL-1 $\beta$, IL-6, IL-8, and endotoxin in 10 patients undergoing normothermic $\mathrm{CPB}$ for cardiac surgery. Indeed, cytokine production has been studied only after hypothermic CPB, and to our knowledge no data are available concerning normothermic $\mathrm{CPB}$.

\section{Patients and methods}

Patients. After approval by the local ethics committee, 10 patients were prospectively included for the study. They underwent a valve operation with normothermic CPB. Their ages ranged from 23 to 83 years $(46.8 \pm 16$ years, mean \pm standard deviation). No corticosteroids were administered before or during the study. Patients with suspected infectious disease were excluded. Details on patients and length of CPB are summarized in Table $\mathbf{I}$.

Radial and pulmonary arterial catheters were introduced with the aid of local anesthesia. Anesthetic induction and maintenance were achieved with high doses of fentanyl, pancuronium bromide, and midazolam. The extracorporeal circuit consisted of a roller pump (Cobe Stöckert, Stöckert Instrument, Rungis, France), a cardiotomy reservoir, and a Sorin membrane oxygenator (Sorin Laboratories, Mirandola, Italy). The circuit was primed with $1500 \mathrm{ml}$ of Ringer's lactate solution, sodium bicarbonate, and gelatin. Heparin ( $400 \mathrm{UI} / \mathrm{kg}$ body weight) was injected into the right atrium before cannulation, to achieve an activated clotting time of more than 400 seconds. Flow rates of $2.4 \mathrm{~L} \cdot \mathrm{m}^{2} \cdot \mathrm{mm}^{-1}$ were used. Normothermia (temperature $>36.5^{\circ} \mathrm{C}$ ), assessed by the monitoring of bladder temperature, was assured during the operation and CPB. Ultrafiltration was never performed during the study. Myocardial protection was achieved by cold blood cardioplegic solution infused every 30 minutes. Before aortic unclamping, reperfusion was performed with the same blood cardioplegic solution at $37^{\circ} \mathrm{C}$. Heparin was
Table I. Demographic data

\begin{tabular}{lclc}
\hline $\begin{array}{c}\text { NYHA } \\
\text { class }\end{array}$ & $\begin{array}{c}\text { Age } \\
(y \boldsymbol{r})\end{array}$ & \multicolumn{1}{c}{ Operation } & $\begin{array}{c}\text { CPB } \\
\text { duration } \\
(\text { min })\end{array}$ \\
\hline IV & 35 & AVR, MVR, & 119 \\
& & TV Ann & \\
III & 83 & AVR, CABG & 103 \\
IV & 33 & AVR, MVR & 135 \\
III & 81 & MVR & 60 \\
II & 31 & Mitral & 126 \\
& & valvuloplasty, & \\
II & 26 & AVR, MVR & 122 \\
III & 69 & AVR, MVR & 132 \\
IV & 23 & AVR, MVR & 107 \\
III & 59 & MVR & 88 \\
II & 28 & AVR, Bentall & 140 \\
& & procedure & \\
\hline
\end{tabular}

$N Y H A$, New York Heart Association; $A V R$, aortic valve replacement; $M V R$, mitral valve replacement; $T V A n n$, tricuspid valve annuloplasty; $C A B G$, coronary artery bypass grafting.

neutralized with protamine sulfate, at a ratio of $1: 3$, within 10 minutes after the end of CPB.

Serial blood samples $(5 \mathrm{ml})$ were withdrawn from the radial artery catheter before sternotomy (T0); at the beginning of $\mathrm{CPB}$ (HO); and at intervals of $1,2,4,6,10$, and 24 hours $(\mathrm{H} 1$ to $\mathrm{H} 24)$ after the beginning of $\mathrm{CPB}$. Blood samples were collected into sterile vacuum tubes with ethylenediaminetetraacetic acid and immediately centrifuged. An aliquot of plasma was obtained and stored at $-70^{\circ} \mathrm{C}$ until cytokine and endotoxin assays were performed. Mean arterial pressure, cardiac index (assessed by thermodilution), systemic vascular resistances, and bladder temperature were recorded all along the study.

Enzyme immunoassays for IL-1 $\beta$, IL-6, IL-8, and TNF $\alpha$. The levels of plasma immunoreactive IL- $1 \beta$, IL-6, IL-8, and TNF $\alpha$ were determined by immunoenzymatic assays according to the manufacturer's procedure. IL- $1 \beta$, IL-6, IL-8, and TNF $\alpha$ enzyme-linked immunosorbent assays were from Amersham (Biotrak, Les Ulis, France). The detection limits were $3 \mathrm{pg} / \mathrm{ml}$ for IL- $1 \beta$ and IL-6, $10 \mathrm{pg} / \mathrm{ml}$ for TNF $\alpha$, and $18 \mathrm{pg} / \mathrm{ml}$ for IL-8. Results were not corrected for hemodilution.

Measurement of endotoxins. Endotoxin was determined using the Limulus amebocyte lysate assay from TechGen (Limusate, Les Ulis, France). The sensitivity of this assay was $0.06 \mathrm{EU} / \mathrm{ml}$.

Statistical analysis. The data were analyzed by analysis of variance. Correlations between peak cytokine values and different parameters were assessed by Spearman's rank correlation. Significance was accepted when $p$ was less than 0.05 . Results are expressed as mean \pm standard deviation.

\section{Results}

Patients. Table I shows the clinical characteristics and operative procedures for the 10 patients. Mean CPB and aortic clamping durations were $113.2 \pm 17.6$ and $88.7 \pm 16.5$ minutes, respectively. Temperature was $36.7^{\circ} \pm 0.4^{\circ} \mathrm{C}$ during $\mathrm{CPB}$ and reached a maximal value of $37.7^{\circ} \pm 0.6^{\circ} \mathrm{C}$ at $\mathrm{H} 10$. All of the patients recov- 


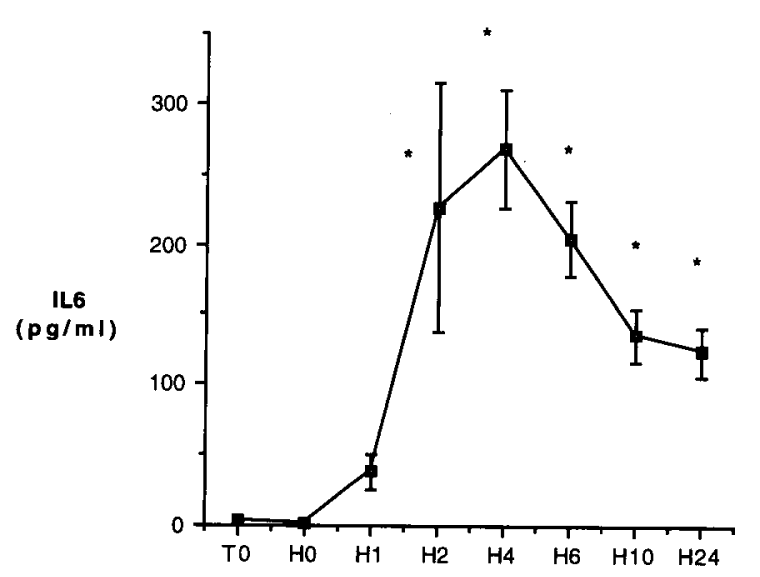

Fig. 1. Effect of CPB on plasma IL-6 concentration (mean \pm standard error of the mean). Time points: TO, after induction; $H O$, at the beginning of CPB; and $1,2,4,6,10$, and 24 hours after the beginning of $\mathrm{CPB} .\left({ }^{*} p<0.05\right.$ versus T0.)

ered uneventfully, except one patient who required surgical hemostasis for major bleeding at $\mathrm{H} 12$.

\section{Cytokines and endotoxin.}

$I L-1 \beta$ and $T N F \alpha$. Il- $1 \beta$ was never detectable in our 10 patients until H24. TNF $\alpha$ was undetectable except in three patients. When detectable, plasma TNF $\alpha$ concentrations were low $(<100 \mathrm{pg} / \mathrm{ml})$ and no correlation was found with operative times.

$I L-6$. Fig. 1 shows changes in plasma concentration of IL-6. Plasma IL-6 was detectable in one patient at T0 (12 $\mathrm{pg} / \mathrm{ml})$. Plasma levels remained unchanged after 1 hour of $\mathrm{CPB}$, raised significantly at $\mathrm{H} 2$, and peaked 4 hours after the start of CPB, remaining above baseline values 24 hours after $\mathrm{CPB}$. The mean peak value at $\mathrm{H} 4$ was $268.1 \pm 131.43 \mathrm{pg} / \mathrm{ml}$. IL-6 plasma levels rose significantly in all patients.

$I L-8$. Changes in plasma levels of IL-8 are shown in Fig. 2. Three patients had low levels of IL-8 at T0 $(30,34$, and $110 \mathrm{pg} / \mathrm{ml})$. Plasma IL-8 concentration rose in all of the patients after the start of CPB, peaked at $\mathrm{H} 2$ $(370 \pm 420 \mathrm{pg} / \mathrm{ml})$, and remained significantly elevated until H6. Values at $\mathrm{H} 10$ and $\mathrm{H} 24$ were not significantly above the baseline level, but IL- 8 was still detectable in seven patients 24 hours after CPB. In two patients, IL- 8 was not measured at $\mathrm{H} 24$, for technical reasons. Peak values were greater than $1000 \mathrm{pg} / \mathrm{ml}(1497 \mathrm{pg} / \mathrm{ml})$ in only one patient. Interestingly, IL-6 concentration was also the highest at this time $(838 \mathrm{pg} / \mathrm{ml})$, in contrast to IL- $1 \beta$ and TNF $\alpha$, which remained undetectable.

Endotoxin. Endotoxin was not detected in the plasma at any time of the study in any of the patients.

Correlation between changes in cytokine levels and hemodynamic data. There was no correlation between

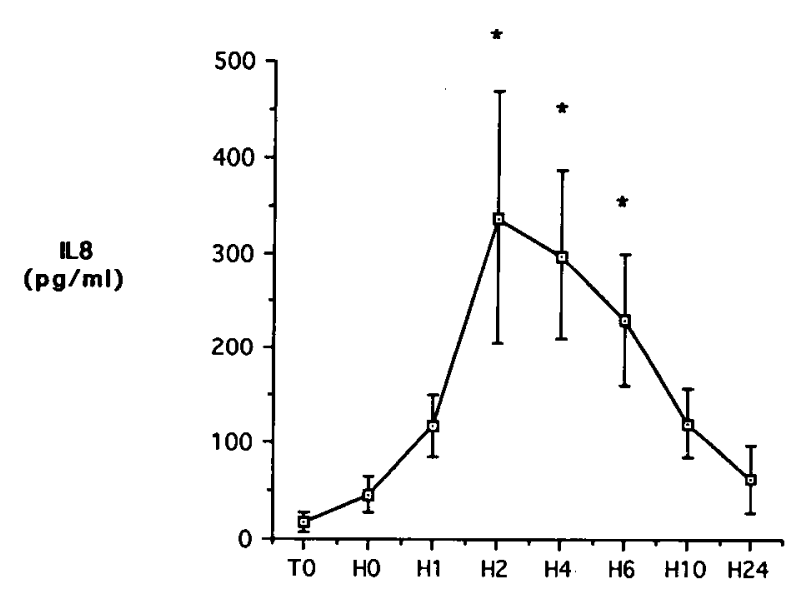

Fig. 2. Effect of CPB on plasma IL-8 concentration (mean \pm standard error of the mean). Time points are those depicted in the legend to Fig. $1 .\left(^{*} p<0.05\right.$ versus T0.)

peak levels of IL-6 or IL-8 and CPB or aortic clamping durations. Fig. 3 shows mean arterial pressure and systemic vascular resistances during the study. No correlation was found between either IL- 6 or IL-8 concentrations and mean arterial pressure, cardiac output, or systemic vascular resistances.

\section{Discussion}

By contrast to the numerous data on cytokine release after hypothermic CPB, to our knowledge no data are available after normothermic CPB. This lack led us to measure, in 10 patients undergoing normothermic $\mathrm{CPB}$, circulating levels of the main cytokines that could be involved in postoperative organ failure. We found an increase in plasma IL-6 and IL-8 concentrations after normothermic CPB, whereas IL- $1 \beta$ and TNF $\alpha$ remained undetectable. Warm heart surgery was introduced a few years ago, but few prospective studies have been reported concerning the innocuousness of this technique. ${ }^{23,24}$ Some previous studies concerning warm heart surgery reported lower systemic vascular resistance with this technique when compared with hypothermia, the "gold standard." ${ }^{26,27}$ Warm heart surgery could increase vasopressor requirements. ${ }^{26}$ Greater blood viscosity might contribute to increased systemic vascular resistance during hypothermia, but the possibility of an enhanced cytokine production after normothermic CPB has not been explored. Indeed, the temperature has a major influence on the different inflammatory pathways activated during CPB. Neutrophilia during CPB is prevented by hypothermia but reappears quickly when the body temperature is restored to $36^{\circ} \mathrm{C} .{ }^{28} \mathrm{In}$ vitro, hypothermia reduces complement activation and inhibits IL- $1 \beta$ pro- 
duction by monocytes. ${ }^{9}$ Furthermore, clinical investigations have reported increased levels of cytokine only after rewarming of the patients. $9,11,14,21,29$

In hypothermia, conflicting data are available concerning circulating levels of TNF $\alpha$ or IL- $1 \beta$. In many studies, plasma IL- $\beta$ and TNF $\alpha$ have not been detected after hypothermic $\mathrm{CPB},{ }^{8,10,12,13,21}$ except in some patients of two studies. ${ }^{14,15}$ Some possibilities might explain the discrepancies. During CPB, variable levels of endotoxin have been reported, ${ }^{14,30,31}$ with enhanced plasma levels of $\mathrm{TNF}^{32}$ Endotoxin was not detected in the plasma of our patients. The short half-life of TNF $\alpha$ and IL- $1 \beta$ and differences between methods of cytokine measurement might also explain discrepancies between different studies. Bioassays detect biologic activity, measured in vitro on specific cells. By contrast, immunoassays measure serum antigens. The latter may detect complexes of cytokine and cytokine-soluble receptor or cytokine inhibitor as free cytokine and thus provide false-positive levels, when compared with bioassays. ${ }^{33}$ Furthermore, the absence of detectable circulating cytokines does not exclude a likely local production by activated cells. ${ }^{34}$

In our study, we did not find significant levels of circulating TNF $\alpha$ or IL- $1 \beta$ after normothermic CPB. This argues against a deleterious effect of normothermic $\mathrm{CPB}$ with an exacerbated production of these two cytokines, which might induce vasodilation and contribute to postoperative complications. Moreover, systemic vascular resistance did not decrease significantly in our patients. Only two patients required injection of phenylephrine $(250$ and $500 \mu \mathrm{g})$ to maintain systemic perfusion pressure above $50 \mathrm{~mm} \mathrm{Hg}$. Anesthetic management with high doses of fentanyl and neither halothane nor isoflurane might explain hemodynamic stability. Moreover, in our study myocardial protection was obtained with intermittent cold blood cardioplegia and not with continuous warm cardioplegia.

IL-6, known to have pleiotropic functions, is one of the key mediators in the acute phase response. ${ }^{35}$ In the present study, plasma IL-6 levels increased significantly 2 hours (H2) after the start of CPB, peaked at $\mathrm{H} 4$, and remained elevated at $\mathrm{H} 24$. The peak was earlier than peaks observed after moderate hypothermic CPB, and thus normothermic $\mathrm{CPB}$ seems to quicken the inflammatory response. Nevertheless, although constantly observed after cardiac operations, a rise in plasma IL-6 levels is not specific to CPB because it also occurs after major noncardiac operations. ${ }^{36-40}$

Neutrophil activation has been documented after CPB, with the release of the peroxidation products, ${ }^{7}$ myeloperoxidase, ${ }^{6}$ lactoferrin, and elastase. ${ }^{6,10}$ The role of neutrophil activation in lung and myocardial injuries has been
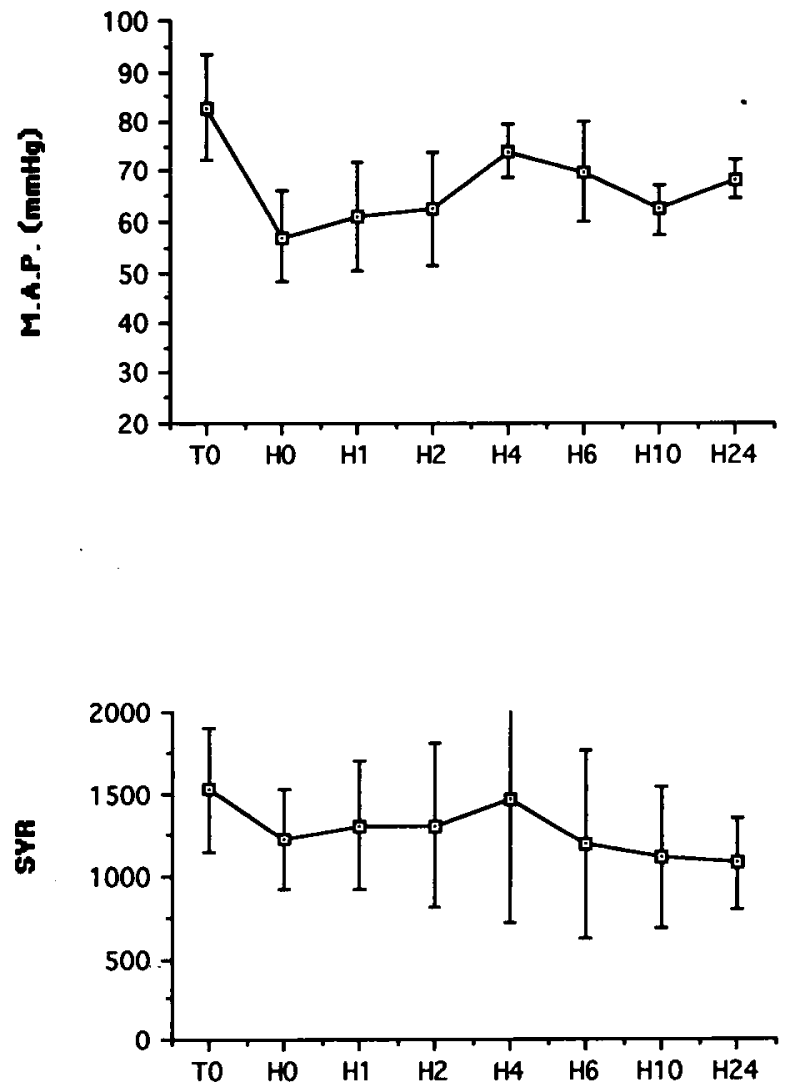

Fig. 3. Changes in mean arterial pressure (M.A.P., $\mathrm{mm} \mathrm{Hg}$ ) and systemic vascular resistances $\left(S V R\right.$, dyne $\left.\cdot \mathrm{sec} / \mathrm{cm}^{5}\right)$ with time in 10 patients undergoing normothermic $C P B$. Results are expressed as mean \pm standard deviation.

well documented in experimental or human investigations. ${ }^{2,6,7,41-43}$ This led us to measure IL-8, a potent neutrophil chemotactic and activating factor. ${ }^{19}$ Our results show an early increase in plasma IL-8 levels, with peak levels 2 hours after the beginning of CPB. The fact that peak values were not correlated with the length of aortic clamping or bypass might be due to the homogeneous durations of CPB in our patients. Recently, a rise in plasma IL-8 levels has been reported after hypothermic CPB. ${ }^{11,21,22}$ Even if comparisons must be done with caution, it appears that normothermic CPB induces a pattern of IL-8 production similar to that observed with hypothermic CPB. ${ }^{11,21,22}$

IL-8 production does not seem to be specific to cardiac surgery, but rather to situations of ischemia-reperfusion or anoxia-hyperoxia injuries. ${ }^{21,22,44}$ Lung reperfusion injury in rabbits has been shown to be prevented by a monoclonal antibody against IL-8. ${ }^{20}$ These studies emphasized the major role that IL-8 might play in the reperfusion injury described after cardiac operations. 
Thus we are now investigating the clinical relevance of IL-8 secretion on pulmonary function and neutrophil activation during normothermic CPB.

The cells involved in the production of IL-8 after cardiac surgery remain to be determined. Pulmonary production by alveolar macrophages might be a potent source of IL-8. Furthermore, high levels of this cytokine have been detected in the bronchoalveolar lavage fluid of patients after CPB..$^{22,45} \mathrm{~A}$ local production of TNF $\alpha$ and IL- $1 \beta$, even if undetectable in the circulation, could induce IL- 8 synthesis and secretion.

In conclusion, our study shows that normothermic CPB is associated with IL-6 and IL-8 production, which is similar to that previously observed after hypothermic CPB. Plasma levels of TNF $\alpha$ and IL-1 $\beta$ remain undetectable in our patients after $\mathrm{CPB}$, results that are consistent with previous studies concerning hypothermic $\mathrm{CPB}$. Our results suggest that normothermic $\mathrm{CPB}$ per se does not induce an overproduction of cytokines when compared with hypothermic $\mathrm{CPB}$.

\section{REFERENCES}

1. Westaby $\mathrm{S}$. Organ dysfunction after cardiopulmonary bypass: a systemic inflammatory reaction initiated by the extracorporeal circuit. Intensive Care Med 1987;13:89-95.

2. Butler J, Rocker GM, Westaby S. Inflammatory response to cardiopulmonary bypass. Ann Thorac Surg 1993; 55:552-9.

3. Knudsen F, Andersen LW. Immunological aspects of cardiopulmonary bypass. J Cardiothorac Vasc Anesth 1990;4:245-58.

4. Kirklin JK, Westaby S, Blackstone EH, Kirklin JW, Chenoweth DE, Pacifico AD. Complement and the damaging effects of cardiopulmonary bypass. J THORAC CARDIOVASC SURG 1983;86:845-57.

5. Moore FD, Warner KG, Assousa S, Valeri CR, Khuri SF. The effects of complement activation during cardiopulmonary bypass. Ann Surg 1988;208:95-103.

6. Faymonville ME, Pincemail J, Duchateau J, et al. Myeloperoxidase and elastase as markers of leukocyte activation during cardiopulmonary bypass in humans. J THORAC Cardiovasc Surg 1991;102:309-17.

7. Royston D, Fleming JS, Desai JB, Westaby S, Taylor KM. Increased production of peroxidation products associated with cardiac operations: evidence for free radical generation. J Thorac Cardiovasc SURG 1986;91:759-66.

8. Butler J, Chong GL, Baigrie RJ, Pillai R, Westaby S, Rocker GM. Cytokine responses to cardiopulmonary bypass with membrane and bubble oxygenation. Ann Thorac Surg 1992;53:833-8.

9. Haeffner-Cavaillon $\mathrm{N}$, Roussellier $\mathrm{N}$, Ponzio $\mathrm{O}$, et al. Induction of interleukin-1 production in patients undergoing cardiopulmonary bypass. $\mathrm{J}$ THORAC CARDIOvASC SuRG 1989;98:1100-6.

10. Butler J, Pillai R, Rocker GM, Westaby S, Parker D, Shale
DJ. Effect of cardiopulmonary bypass on systemic release of neutrophil elastase and tumor necrosis factor. J THORAC Cardiovasc Surg 1993;105:25-30.

11. Kawamura T, Wakusawa R, Okada K, Inada S. Elevation of cytokines during open heart surgery with cardiopulmonary bypass: participation of interleukin 8 and 6 in reperfusion injury. Can J Anaesth 1993;40:1016-21.

12. Almdahl SM, Waage A, Ivert T, Vaage J. Release of bioactive interleukin 6 but not of tumour necrosis factor- $\alpha$ after elective cardiopulmonary bypass. Perfusion 1993;8: 233-8.

13. Markewitz A, Faist E, Lang S, Endres S, Hültner L, Reichart B. Regulation of acute phase response after cardiopulmonary bypass by immunomodulation. Ann Thorac Surg 1993;55:389-94.

14. Jansen NJ, van Oeveren W, Gu YJ, van Vliet MH, Eijsman L, Wildevuur CR. Endotoxin release and tumor necrosis factor formation during cardiopulmonary bypass. Ann Thorac Surg 1992;54:744-8.

15. Laidler J, Paes ML, Wheeler J, Freeman R, Robertson H. Detection of circulating tumour necrosis factor $-\alpha$ after elective cardiopulmonary bypass. Perfusion 1991;6:51-4.

16. Beasley D, Cohen RA, Levinski NG. Interleukin 1 inhibits contraction of vascular smooth muscle. J Clin Invest 1989;83:331-5.

17. Bernard C, Tedgui A. Cytokine network and the vessel wall: insights into septic shock pathogenesis. Eur Cytokine Netw 1992;3:19-33.

18. Gulick T, Chung MK, Pieper SJ, Lange LG, Schreiner GF. Interleukin 1 and tumor necrosis factor inhibit cardiac myocyte $\beta$-adrenergic responsiveness. Proc Natl Acad Sci U S A 1989;86:6753-7.

19. Kunkel SL, Standiford T, Kasahara K, Strieter RM. Interleukin-8 (IL-8): the major neutrophil chemotactic in the lung. Exp Lung Res 1991;17:17-23.

20. Sekido N, Mukaida N, Harada A, Nakanishi I, Watanabe $\mathrm{Y}$, Matsushima K. Prevention of lung reperfusion injury in rabbits by a monoclonal antibody against interleukin- 8 . Nature 1993;365:654-7.

21. Finn A, Naik S, Klein N, Levinsky RJ, Strobel S, Elliot M. Interleukin- 8 release and neutrophil degranulation after pediatric cardiopulmonary bypass. J THORAC CARDIOVASC SURG 1993;105:234-41.

22. Jorens $P G$, de Jongh $R$, de Backer $W$, et al. Interleukin-8 production in patients undergoing cardiopulmonary bypass: the influence of pretreatment with methylprednisolone. Am Rev Respir Dis 1993;148:890-5.

23. Lichtenstein SV, Ashe KA, El-Dalati H, Cusimano RJ, Panos A, Slutsky AS. Warm heart surgery. J THORAC Cardiovasc Surg 1991;101:269-74.

24. Vaughn CC, Opie JC, Florendo FT, Lowell PA, Austin J. Warm blood cardioplegia. Ann Thorac Surg 1993; 55:1227-32.

25. Yau TM, Carson S, Weisel RD, et al. The effect of warm heart surgery on postoperative bleeding. J THORAC CARDIOVASC SURG 1992;103:1155-63.

26. Christakis GT, Koch JP, Deemar KA, et al. A randomized 
study of the systemic effects of warm heart surgery. Ann Thorac Surg 1992;54:449-59.

27. Lehot JJ, Villard J, Piriz H, et al. Hemodynamic and hormonal responses to hypothermic and normothermic cardiopulmonary bypass. J Cardiothorac Vasc Anesth 1992; 6:132-9.

28. Quiroga MM, Miyagishima R, Haendschen LC, Glovsky M, Martin BA, Hogg JC. The effect of body temperature on leukocyte kinetics during cardiopulmonary bypass. J Thorac Cardiovasc Surg 1985;90:91-6.

29. Sakai T, Latson TW, Whitten CW, et al. Perioperative measurements of interleukin-6 and a-melanocyte-stimulating hormone in cardiac transplant patients. J Cardiothorac Vasc Anesth 1993;7:17-22.

30. Karlstad MD, Patteson SK, Guszcza JA, Langdon R, Chesney JT. Methylprednisolone does not influence endotoxin translocation during cardiopulmonary bypass. J Cardiothorac Vasc Anesth 1993;7:23-7.

31. Kharazmi A, Andersen LW, Baek L, Valerius NH, Laub M, Rasmussen JP. Endotoxemia and enhanced generation of oxygen radicals by neutrophils from patients undergoing cardiopulmonary bypass. J THORAC CARdIovasC SuRG 1989;98:381-5.

32. Dauber IM, Parsons PE, Welsh $\mathrm{CH}$, et al. Peripheral bypass-induced pulmonary and coronary vascular injury: association with increased levels of tumor necrosis factor. Circulation. 1993;88:726-35.

33. Olsson I, Gatanaga T, Gullberg U, Lantz M, Granger GA. Tumour necrosis factor (TNF) binding proteins (soluble TNF receptor forms) with possible roles in inflammation and malignancy. Eur Cytokine Netw 1993;4:169-80.

34. Cavaillon JM, Munoz C, Fitting C, Misset B, Carlet J. Circulating cytokines: The tip of the iceberg? Circ Shock 1992:38:145-52.

35. Nijsten MW, DeGroot ER, Tenduis HJ, Klesen HJ, Hack CE, Aarden LA. Serum levels of interleukin 6 and acute phase responses. Lancet 1987;2:921.

36. Cruickshank AM, Fraser WD, Burns HJ, Van Damme J, Shenkin A. Response of serum interleukin-6 in patients undergoing elective surgery of varying severity. Clin Sci 1990;79:161-5.

37. Di Padova F, Pozzi C, Tondre MJ, Tritapepe R. Selective and early increase of IL-1 inhibitors, IL-6 and cortisol after elective surgery. Clin Exp Immunol 1991;85:137-42.

38. Naito Y, Tamai S, Shingu K, et al. Responses of plasma adrenocorticotropic hormone, cortisol, and cytokines during and after upper abdominal surgery. Anesthesiology 1992;77:426-31.

39. Ohzato $\mathrm{H}$, Yoshizaki K, Nishimoto N, et al. Interleukin-6 as a new indicator of inflammatory status: detection of serum levels of interleukin- 6 and C-reactive protein after surgery. Surgery 1992;111:201-9.

40. Parry-Billings M, Baigrie RJ, Lamont PM, Morris PJ, Newsholme EA. Effects of major and minor surgery on plasma glutamine and cytokine levels. Arch Surg 1992;127:1237-40.

41. Bator JM, Gillinov AM, Zehr KJ, et al. NPC 15669 blocks neutrophil CD18 increase and lung injury during cardiopulmonary bypass in pigs. Mediators Inflammation 1993;2:135-41.

42. Byrne JG, Smith WJ, Murphy MP, Couper GS, Appleyard RF, Cohn LH. Complete prevention of myocardial stunning, contracture, low-reflow, and edema after transplantation by blocking neutrophil adhesion molecules during reperfusion. J THORAC Cardiovasc SURG 1992;104: 1589-96.

43. Goldman G, Welbourn R, Rothlein R, et al. Adherent neutrophils mediate permeability after atelectasis. Ann Surg 1992;216:372-80.

44. Metinko AP, Kunkel SL, Standiford J, Strieter RM Anoxia-hyperoxia induces monocyte-derived interleukin-8. J Clin Invest 1992;90:791-8.

45. Jorens PG, Van Damme J, de Backer W, et al. Interleukin-8 (IL-8) in the bronchoalveolar lavage fluid from patients with the adult respiratory distress syndrome (ARDS) and patients at risk for ARDS. Cytokine 1992:4.592-7. 